\title{
STEREOCHEMISTRY OF THE Pd $\left(\mathrm{PPh}_{3}\right)_{4}$-CATALYZED CONVERSION OF 1-BROMOALLENES INTO PHENYL SUBSTITUTED ALLENES.
}

\author{
C.J. Elsevier, H.H. Mooiweer, H. Kleijn and P. Vermeer \\ Department of Organic Chemistry, State University at Utrecht, \\ Croesestraat 79, 3522 AD Utrecht, The Netherlands
}

Summary: 1-Bromoallenes $\underset{\sim}{1}$ are converted into the phenyl substituted allenes 2 with inversion of configuration in the allenyl moiety by reaction with $\mathrm{Ph}_{2} \mathrm{Zn}$ using $\mathrm{Pd}\left(\mathrm{PPh}_{3}\right)_{4}$ as catalyst.

A number of years ago it was found that 1-bromoallenes are converted into alkyla1lenes by lithium dialkylcuprates. 1 In a recent study it was reported that such reactions may occur with inversion of configuration in the allenyl moiety. ${ }^{2}$

This paper discloses the stereochemical course of the $\mathrm{Pd}\left(\mathrm{PPh}_{3}\right)_{4}$-catalyzed conversion of 1-bromoallenes by $\mathrm{Ph}_{2} \mathrm{Zn}$. Previous work in these laboratories showed that 1-bromoallenes react with organozinc compounds to give substituted allenes in excellent yields when $\left.\mathrm{Pd}_{(\mathrm{PPh}}\right)_{4}$ is applied as catalyst. 3 Similar to the Pd(0)-catalyzed conversion of vinylic halides by organometallic species 4 we expected to find retention of configuration for our reaction.

For our study we prepared two optica11y active 3-substituted-1-bromoallenes, viz, (-)-1a and (-)-1 $\underset{\sim}{\mathrm{b}}$, following the procedure which we have described elsewhere. 5 The absolute configuration of both allenes is $R .{ }^{6}$ Addition of $(-)-1$ ( $\left.3.0 \mathrm{mmol}\right)$, at $-60^{\circ} \mathrm{C}$, to a stirred solution of pure $\mathrm{Ph}_{2} \mathrm{Zn}(2.0 \mathrm{mmol})$ and the catalyst $\mathrm{Pd}\left(\mathrm{PPh}_{3}\right)_{4}(0.12 \mathrm{mmol})$ in THF (2l ml), followed by stirring the resulting mixture during $5 \mathrm{~min}$ at $0^{\circ} \mathrm{C}(\underset{\sim}{1 \mathrm{a}})$ or during $15 \mathrm{~min}$ at $20^{\circ} \mathrm{C}(1 \mathrm{~b})$, resulted in excellent conversions (>98\%) of (-)-1 into the dextrorotatory pheny1 substituted allenes 2 . The configuration of both allenes 2 is therefore $S .6$ This means that the conversions of $\underset{\sim}{1 \mathrm{a}}$ and $\underset{\sim}{1 \mathrm{~b}}$ into $\underset{\sim \sim}{2 \mathrm{a}}$ and $\underset{\sim \sim}{2 \mathrm{~b}}$, respective1y, proceed with inversion of configuration. ${ }^{7}$<smiles>[R][C]=C=CBr</smiles>

(R)

$$
\begin{aligned}
& (-)-\underset{\sim}{1 a}: R=P h \\
& (-)-\underset{\sim}{1} \mathbf{b}: R=t-B u
\end{aligned}
$$

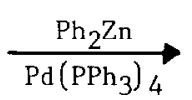

$\mathrm{Pd}\left(\mathrm{PPh}_{3}\right)_{4}$<smiles>[R]C=C=C([2H])c1ccccc1</smiles>

(S)

The $[\alpha]_{\mathrm{D}}^{20}$-values $(\mathrm{EtOH})$ for $2 \mathrm{\sim}$ and $\underset{\sim}{2 b}$ amounted to $+985^{\circ}$ and $+268^{\circ}$, respectively. When it is assumed that the values for optically pure $2 \mathrm{a}{ }^{8 \mathrm{a}}$ and $\underset{\sim}{2 \mathrm{~b}} 8 \mathrm{~b}$ are $+1137^{\circ}$ and $+370^{\circ}$, respectively, the enantiomeric excess of $(S)-2 \mathrm{a}$ amounts to $87 \%$ and that of $(S)-2 \mathrm{~b}$ to $73 \%$. 
The obtained stereochemical result can be rationalized as follows. In the first step of the reaction the catalytically active species $\mathrm{Pd}\left(\mathrm{PPh}_{3}\right)_{2}{ }^{9}$ will induce an anti $\mathrm{S}_{\mathrm{N}} 2^{\prime}-$ reaction in allene $\underset{\sim}{1}$ to give the 2 -propynylic palladium(II) intermediate $\underset{\sim}{3}$ (see Scheme). A suprafacial [1.3]-shift in $\underset{\sim}{3}$ then produces the allenic compound $\underset{\sim}{4}$. Reaction of compound $\underset{\sim}{4}$ with $\mathrm{Ph}_{2} \mathrm{Zn}$ gives the diorganopalladium(II) species 5. 10 This process will proceed with retention of configuration in the allenyl moiety. Subsequent reductive elimination of (+)-2 from complex 5 , also

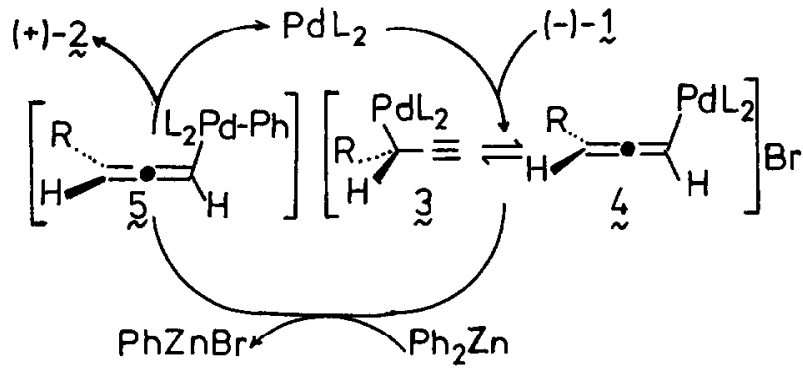

Scheme here with retention of configuration in the the allenyl group, completes the catalytic cycle. This rationale is similar to that proposed by us for the reaction of 2-propynylic esters with organozinc reagents in the presence of the same catalyst. 11

\section{References and notes}

1. M. Kalli, P.D. Landor and S.R. Landor, I. Chem. Soc., Perkin I, 1347 (1973);

P. Savignac, A. Breque, C. Charrier and F. Mathey, Synthesis, 832 (1979).

2. E.J. Corey and N.W. Boaz, Tetrahedron Lett., 25 (1984) 3059.

3. K. Ruitenberg, H. Kleijn, H. Westmijze, J. Meijer and P. Vermeer, Recl. Trav. Chim. Pays-Bas, 101 (1982) 405.

4. For instance, see A.O. King, N. Okukado and E. Negishi, J. Chem. Soc., Chem. Commun., 683 (1977).

5. C.J. Elsevier, J. Meijer, G. Tadema, P.M. Stehouwer, H.J.T. Bos, P. Vermeer and W. Runge, J. Org. Chem., 47 (1982) 2194. For $\underset{\sim}{1 \mathrm{~b}}$ the experimental procedure was modified as follows: a solution of $\mathrm{t}-\mathrm{BuCH}\left(\mathrm{OSO}_{2} \mathrm{Me}\right) \mathrm{C} \equiv \mathrm{CH}(0.01 \mathrm{~mol})$ and $\mathrm{I}_{\mathrm{iCuBr}}(0.02 \mathrm{~mol})$ in $\mathrm{THF}$ ( $40 \mathrm{~m} 1$ ) was refluxed for $2 \mathrm{~h}$ and then worked up.

6. See ref.5 and: C.J. Elsevier, H.J.T. Bos and P. Vermeer, J. Org. Chem., 49 (1984) 379.

7. $[\alpha]_{\mathrm{D}}^{20}$-values (EtOH): $-1235^{\circ}$ for $(R)-\underset{\sim}{\mathrm{la}}$ and $-230^{\circ}$ for $(R)-\underset{\sim}{1 \mathrm{~b}}$. The \% ee is not known but is probably very high (cf. ref.5 and 6).

8. (a) P. Rossi and P. Diversi, Synthesis, 25 (1973);

(b) C.J. Elsevier, Ph. D. Thesis, Utrecht (1984).

9. P.M. Maitlis, P. Espinet and M.J.H. Russell in: G. Wilkinson (Ed), "Comprehensive Organometallic Chemistry", Pergamon Press, Oxford, 1982, Vol. 6, p. 250.

10. The $\mathrm{PhZnBr}$, which is liberated, can participate in another cycle.

11. C.J. Elsevier, P.M. Stehouwer, H. Westmijze and P. Vermeer, J. Org. Chem., 48 (1983) 1103. (Received in UK 11 September 1984) 